\title{
Molecular, structural and biochemical characterization of a novel recombinant chlorophyllase from cyanobacterium Oscillatoria acuminata PCC 6304
}

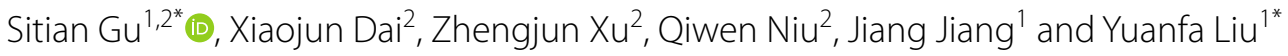

\begin{abstract}
Background: Chlorophyllase catalyzes the hydrolysis of chlorophyll and produces chlorophyllide and phytol. Cyanobacterial chlorophyllases are likely to be more highly heterologously expressed than plant chlorophyllases. A novel recombinant chlorophyllase from the cyanobacterium Oscillatoria acuminata PCC 6304 was successfully expressed in Escherichia coli BL21(DE3).

Results: The putative N-terminal 28-amino-acid signal peptide sequence of $O$. acuminata chlorophyllase (OaCLH) is essential for its activity, but may confer poor solubility on OaCLH. The C-terminal fusion of a $6 \times$ His tag caused a partial loss of activity in recombinant $\mathrm{OaCLH}$, but an $\mathrm{N}$-terminal $6 \times$ His tag did not destroy its activity. The optimal pH and temperature for recombinant $\mathrm{OaCLH}$ activity are 7.0 and $40^{\circ} \mathrm{C}$, respectively. Recombinant $\mathrm{OaCLH}$ has hydrolysis activities against chlorophyll a, chlorophyll b, bacteriochlorophyll a, and pheophytin a, but prefers chlorophyll b and chlorophyll a as substrates. The results of site-directed mutagenesis experiments indicated that the catalytic triad of OaCLH consists of Ser159, Asp226, and His258.
\end{abstract}

Conclusions: The high-level expression and broad substrate specificity of recombinant OaCLH make it suitable for genetically engineering and a promising biocatalyst for industrial production, with applications in vegetable oil refining and laundry detergents.

Keywords: Chlorophyllase, Oscillatoria acuminata PCC 6304, Biochemical characteristic, Substrate specificity, Catalytic triad

*Correspondence: gusitian1983@163.com; yfliu@jiangnan.edu.cn ${ }^{1}$ State Key Laboratory of Food Science and Technology, Collaborative Innovation Center of Food Safety and Quality Control in Jiangsu Province, National Engineering Research Center for Functional Food, National Engineering Laboratory for Cereal Fermentation Technology, School of Food Science and Technology, Jiangnan University, 1800 Lihu Road, Jiangsu 214122 Wuxi, People's Republic of China

${ }^{2}$ Wilmar Biotechnology Research \& Development Center Co., Ltd, 200137 Shanghai, People's Republic of China

\section{Background}

Chlorophyll $(\mathrm{Chl})$ is the commonest pigment in nature, occurring widely in plants, algae, and cyanobacteria. Chlorophyllase (Chlase, EC 3.1.1.14) is one of the most important enzyme in the chlorophyll metabolism of all photosynthetic organisms. It catalyzes the hydrolysis of chlorophyll, producing chlorophyllide (Chlide) and phytol [1].

The catalytic activity of chlorophyllase has potential industrial and pharmaceutical applications. It can remove green pigments from edible oils to improve their oxidative stability, and can replace the expensive adsorptive

(c) The Author(s) 2021. This article is licensed under a Creative Commons Attribution 4.0 International License, which permits use, sharing, adaptation, distribution and reproduction in any medium or format, as long as you give appropriate credit to the original author(s) and the source, provide a link to the Creative Commons licence, and indicate if changes were made. The images or other third party material in this article are included in the article's Creative Commons licence, unless indicated otherwise in a credit line to the material. If material is not included in the article's Creative Commons licence and your intended use is not permitted by statutory regulation or exceeds the permitted use, you will need to obtain permission directly from the copyright holder. To view a copy of this licence, visit http://creativeco mmons.org/licenses/by/4.0/. The Creative Commons Public Domain Dedication waiver (http://creativecommons.org/publicdomain/ zero/1.0/) applies to the data made available in this article, unless otherwise stated in a credit line to the data. 
bleaching technique currently used in the edible oil refining industry [2]. The reaction products of chlorophyllase, chlorophyllides and their derivatives, have been shown to have antiviral, antioxidant, antimutagenic, and anticarcinogenic activities in vitro [3-7].

Chlorophyllase activity was first discovered in 1913, and many studies have investigated the physiological and biochemical properties of the chlorophyllases partially or completely purified from various plant and algal species, including Chenopodium album [8], Citrus limon [9], Chlorella regularis [10], and Phaeodactylum tricornutum $[11,12]$. Chlorophyllase is considered a membranebound protein that normally localizes in chloroplasts and the thylakoid membrane [13]. Okazaea et al. demonstrated that the recombinant chlorophyllase from Ginkgo biloba localizes in the thylakoid membranes of the chloroplast [14]. Shemer et al. showed that chlorophyllase from Citrus limon, which is induced by ethylene, localizes in the plastid [9]. However, two chlorophyllases from Arabidopsis thaliana are reported to localize outside the plastid, in the endoplasmic reticulum and tonoplast [15, 16].

Many recombinant plant and algal chlorophyllases, including those from Chenopodium album [17], Triticum aestivum [18], Pachira macrocarpa [19], Citrus sinensis [20], Brassica oleracea [21], and Chlamydomonas reinhardtii [22], have been expressed in the Escherichia coli system and characterized biochemically. However, the heterologous expression of recombinant plant chlorophyllases is usually very low. When Arkus et al. expressed the chlorophyllase of Triticum aestivum (wheat) in $E$. coli, the recombinant target protein content in the growth medium was only $\sim 5 \mathrm{mg} / \mathrm{L}$ [18]. Therefore, plant chlorophyllases are generally difficult to use in industrial applications.

Microbial enzymes are likely to be more highly heterologously expressed than plant enzymes. Like the plant and algal chlorophyllases, the cyanobacterial chlorophyllases play an important role in chlorophyll metabolism of cyanobacteria.

Only a few studies of cyanobacterial chlorophyllase have been reported. Chou et al. isolated and expressed a chlorophyllase from Cyanothece sp. ATCC 51142 in E. coli, which preferentially hydrolyzed bacteriochlorophyll a ( $\mathrm{BChl}$ a) to bacteriochlorophyllide a (BChlide a) and phytol [23]. However, the physiological function of the cyanobacterial chlorophyllases has not been investigated.

Oscillatoria acuminata PCC 6304 is a photosynthetic filamentous cyanobacterium. Its complete chromosomal genomic sequence was fully determined and published in GenBank (NCBI database) in 2012. The putative chlorophyllase sequence was annotated, but has not been investigated. In this study, the chlorophyllaserelated gene (GeneID: 428001063) of O. acuminata PCC 6304 was synthesized and expressed in an E. coli system. The molecular structure, substrate specificity, enzyme kinetics, and biochemical characterization of recombinant $O$. acuminata chlorophyllase $(\mathrm{OaCLH})$ were then investigated.

\section{Results and discussion}

\section{Sequence analysis of recombinant $\mathrm{OaCLH}$}

The nucleotide sequence of $\mathrm{OaCLH}$ contains 978 base pairs, encoding 325 amino acid residues with a calculated molecular mass of $34.78 \mathrm{kDa}$ and a predicted $\mathrm{pI}$ of 4.55 . The TargetP-2.0 server and SignalP-5.0 server predicted the presence of a putative 28 -amino-acid signal peptide at the $\mathrm{N}$-terminal end of the $\mathrm{OaCLH}$ sequence. The signal peptide presumably guides $\mathrm{OaCLH}$ to the thylakoid membrane, in which the chlorophylls and other photosynthetic pigments of cyanobacteria $O$. acuminata PCC 6304 localize. Various physical and chemical parameters of $\mathrm{OaCLH}$, predicted with the ProtParam tool, are shown in Table 1. The estimated half-life of OaCLH is $30 \mathrm{~h}$ in vitro in mammalian reticulocytes, more than $20 \mathrm{~h}$ in vivo in yeast, and more than $10 \mathrm{~h}$ in vivo in E. coli. Its instability index was computed to be 37.42 , which classifies $\mathrm{OaCLH}$ as stable. The calculated aliphatic index (101.14) indicates that OaCLH is thermostable. However, the positive grand average hydropathy (GRAVY) value (0.157) indicates that OaCLH is a poorly hydrophilic protein, which may confer poor solubility. The TMpred server predicted four potential transmembrane domains in the $\mathrm{OaCLH}$ sequence, so OaCLH may be a membranebound protein of O. acuminata PCC 6304.

Recombinant $\mathrm{OaCLH}$ shares a higher degree of amino acid sequence identity with other cyanobacterial chlorophyllases (51-71\%) than with plant chlorophyllases

Table 1 Various physical and chemical parameters of OaCLH predicted with the ProtParam tool

\begin{tabular}{|c|c|c|c|c|c|c|c|c|c|}
\hline \multirow[t]{2}{*}{ Source } & \multirow[t]{2}{*}{ Accession no. } & \multirow{2}{*}{$\begin{array}{l}\text { Molecular } \\
\text { weight }\end{array}$} & \multirow[t]{2}{*}{ pl } & \multicolumn{3}{|c|}{ Estimated half-life (hours) } & \multirow{2}{*}{$\begin{array}{l}\text { Instability } \\
\text { index }\end{array}$} & \multirow{2}{*}{$\begin{array}{l}\text { Aliphatic } \\
\text { index }\end{array}$} & \multirow[t]{2}{*}{ GRAVY } \\
\hline & & & & $\begin{array}{l}\text { mammalian } \\
\text { reticulocytes, } \\
\text { in vitro }\end{array}$ & yeast, in vivo & $\begin{array}{l}\text { E. coli, } \\
\text { in vivo }\end{array}$ & & & \\
\hline $\begin{array}{l}\text { Oscillatoria } \\
\text { acuminata }\end{array}$ & AFY81906.1 & 34783.41 & 4.55 & 30 & $>20$ & $>10$ & 37.42 & 101.14 & 0.157 \\
\hline
\end{tabular}


(25-32\%). Clustal Omega was used to align the amino acid sequence of OaCLH with eight previously reported cyanobacterial chlorophyllase amino acid sequences: from Nostoc sp. PCC 7524, Scytonema tolypothrichoides VB-61278, Chamaesiphon minutus PCC 6605, Cyanobacteria bacterium J007, Chroococcidiopsis cubana CCALA 043, cyanobacterium TDX16, Nostoc punctiforme NIES-2108, and Nostoc sp. CENA543. The multiple sequence alignment (Fig. 1) showed that all these cyanobacterial chlorophyllases share a highly conserved sequence (GHSXG), which is also present in all plant chlorophyllases [24]. Specifically, this conserved motif is GHSRG in plant chlorophyllases, but GHSFG in cyanobacterial chlorophyllases other than OaCLH and chlorophyllase from Cyanobacteria bacterium J007, which contain a GHSWG motif. This conserved motif belongs to all $\alpha / \beta$ hydrolase family domains (pfam12695), which are reported to have several functions and activities similar to those of proteases, lipases, peroxidases, esterases, epoxide hydrolases, and dehalogenases [25]. This conserved motif contains a serine residue, which is responsible for the nucleophilic attack on the carbonyl carbon atom of the ester bond in the hydrolysis reaction. Therefore, the presence of the conserved motif GHSXG underpins the hydrolysis activity of the chlorophyllases.

The multiple sequence alignment also showed that the putative catalytic residues (serine [Ser]-aspartic acid [Asp]-histidine [His]) are strictly conserved in all cyanobacterial chlorophyllases (marked with three black triangles in Fig. 1). The putative catalytic triad of OaCLH may be Ser159, Asp226, and His258.

The predicted tertiary structural model of OaCLH (Fig. 2) was constructed with the SWISS-MODEL program using a template (6scd.1.A) of polyester hydrolase PE-H from Pseudomonas aestusnigri, which is the closest homologue of OaCLH [26]. OaCLH shares $21.30 \%$ identity with the template 6scd.1.A, based on the overall amino acid sequence. The tertiary structural model is composed of seven $\beta$-strands and nine $\alpha$-helices. Active serine residue 159 is located in an extremely sharp turn between a $\beta$-strand and an $\alpha$-helix, called the 'nucleophilic elbow', a conserved structure in the $\alpha / \beta$ hydrolases. However, the predicted structural model lacks the active site lid that is a common feature of the $\alpha / \beta$ hydrolase family and usually lies over the active site. The putative catalytic triad (Ser159, Asp226, and His258) is located on a surface-exposed loop and clusters as the catalytic domain.

\section{Expression and purification of recombinant $\mathrm{OaCLH}$}

The full-length and signal-peptide-deleted nucleotide sequences of the $\mathrm{OaCLH}$ gene were synthesized and cloned into the pET-24a $(+)$ and pET-28a $(+)$ vectors, respectively. Escherichia coli BL21(DE3) cells were transformed with the corrected recombinant expression plasmids to overexpress the genes under induction with isopropyl $\beta$-D-1-thiogalactopyranoside (IPTG). The soluble recombinant $\mathrm{OaCLHs}$ fused with a C-terminal or N-terminal $6 \times$ His tag was purified with $\mathrm{Ni}^{2+}$ affinity chromatography. The expression of the full-length recombinant $\mathrm{OaCLH}$ reached $\sim 150 \mathrm{mg} / \mathrm{L}$ in growth medium, significantly higher than the yield $(5 \mathrm{mg} / \mathrm{L})$ of plant chlorophyllase from Triticum aestivum expressed in E. coli [16], which is the typical level of plant chlorophyllase expression. Therefore, compared with plant chlorophyllases, recombinant $\mathrm{OaCLH}$ is significantly more strongly expressed in E. coli. SDS-PAGE (Fig. 3) showed that the molecular weights of the full-length and truncated OaCLHs corresponded to the calculated molecular masses of the $6 \times$ His-tagged recombinant OaCLHs. SDS-PAGE also demonstrated that the expression level of soluble full-length OaCLH was significantly lower than that of truncated OaCLH. This is attributed to the poor solubility of full-length OaCLH conferred by the putative 28-amino-acid signal peptide.

The specific activities of the purified C-terminally and $\mathrm{N}$-terminally $6 \times$ His-tagged full-length OaCLHs were measured. The results (Fig. 4) showed that the specific activity of C-terminally $6 \times$ His-tagged $\mathrm{OaCLH}$ was significantly lower than that of N-terminally $6 \times$ His-tagged $\mathrm{OaCLH}$. A multiple sequence alignment and predicted tertiary structural model showed that the putative catalytic active center of $\mathrm{OaCLH}$ is located at the $\mathrm{C}$-terminus. Therefore, C-terminal fusion with a $6 \times$ His tag is likely to change the conformation of the active center, leading to a partial loss of chlorophyllase activity. Furthermore, when $\mathrm{N}$-terminally $6 \times$ His-tagged $\mathrm{OaCLH}$ was digested with thrombin to remove its $6 \times$ His tag, the specific activity of the resulting $\mathrm{OaCLH}$ did not differ significantly from that of the $6 \times$ His-tagged protein (data not shown). Therefore, the N-terminal $6 \times$ His tag does not destroy the activity of $\mathrm{OaCLH}$.

(See figure on next page.)

Fig. 1 Multiple amino acid sequence alignment of various cyanobacteria chlorophyllases. These cyanobacteria chlorophyllases are from Oscillatoria acuminata PCC 6304, Nostoc sp. PCC 7524, Scytonema tolypothrichoides VB-61278, Chamaesiphon minutus PCC 6605, Cyanobacteria bacterium J007, Chroococcidiopsis cubana CCALA 043, cyanobacterium TDX16, Nostoc punctiforme NIES-2108, and Nostoc sp. CENA543. Asterisks, colons, and periods represent identity, strong similarity, and weak similarity, respectively. Three black triangles denote the putative catalytic triad: Ser, Asp, and His residues. The predicted signal peptide sequence of $\mathrm{OaCLH}$ is underlined 
$\mathrm{CmCLH}$ $\mathrm{CCCLH}$ CCLH StCLH $\mathrm{NpCLH}$ $\mathrm{NsCLH}$ $\mathrm{NsCCLH}$

$\mathrm{OaCLH}$ $\mathrm{CbCLH}$

$\mathrm{CmCLH}$ CCCLH CCLH StCLH $\mathrm{NpCLH}$ $\mathrm{NsCLH}$ $\mathrm{NsCCLH}$ $\mathrm{OaCLH}$ $\mathrm{CbCLH}$

$\mathrm{CmCLH}$ $\mathrm{CCCLH}$ CCLH StCLH $\mathrm{NpCLH}$ $\mathrm{NsCLH}$ $\mathrm{NsCCLH}$ $\mathrm{OaCLH}$ $\mathrm{CbCLH}$

$\mathrm{CmCLH}$ $\mathrm{CCCLH}$ $\mathrm{CCLH}$ StCLH $\mathrm{NpCLH}$ $\mathrm{NsCLH}$ $\mathrm{NSCCLH}$ $\mathrm{OaCLH}$ $\mathrm{CbCLH}$

$\mathrm{CmCLH}$ $\mathrm{CCCLH}$ $\mathrm{CCLH}$

StCLH $\mathrm{NpCLH}$ $\mathrm{NsCLH}$ $\mathrm{NsCCLH}$

OPCH $\mathrm{CbCLH}$

CmCLH $\mathrm{CCCLH}$ $\mathrm{CCLH}$

StCLH

$\mathrm{NpCLH}$

$\mathrm{NsCLH}$

$\mathrm{NsCCLH}$

$\mathrm{OaCLH}$

$\mathrm{CbCLH}$

$\mathrm{CmCLH}$

$\mathrm{CCCLH}$

$\mathrm{CCLH}$

StCLH

$\mathrm{NpCLH}$

$\mathrm{NsCLH}$

$\mathrm{NsCCLH}$

$\mathrm{OaCLH}$

$\mathrm{CbCLH}$

-...... - MEKLC - . . . - - AATPOL - - ETSLAROKNYLSPIRSGSSGVNTPHSGIC MLQELLIFALKHASINRETIETQQNPRIEILASELSRSQKLVFDL-DGS - - LNV - -TETA - MIETLKHPRIEVLASELSRSQKLAFDL-DGS--LNV- -TETA -MNELSSKOSS-VVMVGAVMIT -........--MIT -MANFLSS-MAVVGALMIT -MSVISRHSS-LAAIGAAFLT MSLIDSRHSS-LATLGAVLVA

K-DLPGKOKTSFSPEPLYKETKSYTTTIATS---GDPADIYYPIAKSNK-CPVEFPIALL L-GEPEAEPTSFSPEPLYDRVKHYTTTIAAD - - -GDLADVYYPVVPST - - -AERLPIVLM L-GEPEADPTSFSPDPLYDQVKHYTTTIAAN- - -GALADIYYPVVRTA- - -APRLPIVLM LGLELSTVAAEFNPDPLFNSATSYSTIIPRSOGGADPADIYYPVLSDTNKNENSLPIALF LGVERSAVGATFNPAPLFESAVSYSTNIPRTDGGVDSTDIYYPVLSSTQTQONSLPIALL LGVEQSAAAATFNPAPQFESAVSYSTTIPRSDGGVDPADIYYPVLSSTDPEQSSLPIALF LGVERSAAAATFNPAPIFDSAANYVTTIPRSDGGVDAAYIYYPVVSNTD--KSSLPIALF LCR--SFPVAAMTPEPMFDTITHFETTIPRTNGENDPADIYYPVVSO----EVSLPLALL VFT--HIPVTAATPEPRFDTVSRFETTIPTAEGTEDPADIYYPAVSTDG - EMRFPLALL

$$
: * *:: \quad: * * \quad:::^{* * *} \quad: *::^{*}:
$$

LGALVDKADYANFAAOVASYGFIVVVPNNERTLSAPTGQ-TITGLFPEPQQINEVLDWM LQGALVDKADYSNYAQIVARYGFVVVVPNNERTRTNPDGQ-TTTGLLAEQQQVNDVLAQM LQGALVDKADYSNYAQIVARYGFVVVVSNNERTITSSDGQ-TTTGLLAEQQQVNDVLNWM LOGALVDKSDYSNFASYVARYGFVVVVPNHVRTAVSPMGS - -VTGFIAEOOOVNDVLTYM LOGALVDKSDYSTFANTVARYGFVVVVPNHLRTAISPMGA--VTGLIAEQQQVNDVLTYI LQGALVDKSDYSTFASTVARYGFVVVVPNHIRTAISPMGA--VTGLLAEQQQVNDVLSYI LOGALVDKSDYSTFASTVARYGFVVVVPNHIRTAISPMGA- -VTGLLAEOQOVNDVLTYM LPGALVDKADYSNFAOTVASYGFVVLVPNRVRTLVNPVSGREFSGLAAEVAOVNEVLAYF LPGALVDKADYSEFASTVASYGFVVVIPNRFRTLTNPISGEKFPGLFAQVEOVNEVLTYM * ******:**: : * *****:*:: *, ** . * $*:$ : $*$ : $: * *$

EAEDVNPDSPIVNIIDPDKLGLLGHSFGGSVGLGASOEDIFVPGISSPNYVQPPELKAGI KEEDAAPGSPIFKIVNTEKLGLLGHSFGGYAGLAAIQ-NICAPAVCSGNYTRPPELKAGI KVENAAPASPIFKIVDTDKLGLLGHSFGGYAGLAAIQ-NICDPSVCSSSYTRPPELKAGI AVLDSNPSSPVANLLDSSKLVLLGHSFGGAVGLAAIQ-DTCIPVFCTGOFNRPKELKGGA QTEKSTPSSPIANSLDPSTLVLLGHSFGGAAGIAAIQ-GQCFPTLCTGNFTRPKELKAGV RNENSTPSLPIADLFDPSTLVLLGHSFGGAVGIAAIQ-GNCFPVLCTETFNRPQELKGGA OSEKSOGTSPVANLLDPSTLVLLGHSFGGAVGIAAIQ-GDCFFVLCTKDFNRPDELKAGV EAEOSNLTSPLAGRVDLSSVGLLGHSWGGAVGLAALO-NICLPLLCTDSFERPEALKAGI EAEATNPDSPLDGLVDPSLLALLGHSWGGAVGLAAIQ-NICPPLLCSESFTRPEVLKAGI

$$
*: \quad .: \text { : : } * * * * * * *, * *^{*} *, \quad \ldots:::^{*} * * * *
$$

FYGTSFRNPV-TD-AVLPLNNODIATGLIVGDRDGVIKP- -GSTTETYDLILNPPKALIT FYGTNFRS ---SSGAFPTIDNQDIPVGLIAGTLDGVADF--GEAASTYVKIQNPPKALIA FYGTNFQSQP-NSGTFPTIDNQDIPVGLIAGTLDGVSDF --GETASTYVKIQDSPKALIA FYGTNFLIGQ-G-GVVPPINNDGIPIALVEGSODSVATP--DEAFATYAOIODPPKALVT FYGTNFRIGQ-SSGGLPIIDNDGIPIALVOGNRDGVANP - -ANAQETYAGIQDPPKAFIT FYGTNFLIGQ-GSGGL-FIDNDGIPMALVQGNLDGVAMP--LNAELTYAAIQDPPKAFIS FYGTNFRIGQ-SSGGLPIIDNDDIPIALVQGNLDSVATP- -ANAQETYAGIODPPKAFIT FYGTTFRDPIOEEVVLLPIANOGIPVGLIAGDRDGVIOGGMDSWATYENIODPPKALVT FYGTTFRDQSQEDVVILPVNNQGIPVGLIAGDRDGVVRGQLDAVVTTYENIQDPPKVLIT

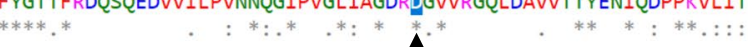

VEGANHYGITNLDNPIREPNRPTLAOSTTTETIARWSGLFLOAHLOGSSGAFDYIYNTGD VKGANHYGITNEDNATRDPNRPTLEQGTATEAIARWSGLFLRSHLLDDRGAFNYVYNNGD VKGANHYGITNEDNATRDPNRPTLEQGTATEAIARWSGLFLRSHLLDDQGAFNYVYNNGD WVGANHYGITNEDNPIREPVRPTLEODVATETIARWSALLLRGTVLNDTGAFNYVFNTGD IPGANHYGITNEDNLIRETVRPTINODVAIETIARWSALFLRGTALNDKNALDYVFNTGD IPGANHYGITNEDNLIRDPIRPTLEQDVAIETIARWSALFLRGTALNDKGAFDYVFNTGD IPGANHYGITNEDNLLREPIRPTLGQDVAIETIARWSALFLRGTVLNDKGAFDYVFNSGD VRGANHYGITNEDS-PRDSVLPTLAOTVATETIARWSALFLRAHLLADAEALNYIYOGGD VLGANHYGITNEDS - IRDPVRPTIAQDLSTETIARWSALFLRAHVLQDSEALNYVYNVGD

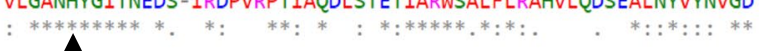

ALDPNVSVISQSPNFGHFSNLP_. DLDPNVSAIGQTPSR - . DLDPNVSAIGQAPAK VLDKNVSIVRVAKSVPEPTSIMGFLGLGVIGINSVLWRKOKLVRK -.... 359 ALDQNVSVESVAKPIPEYTSVVSLLGLGVIGASSLNRKKQKLVKNKVLKF 347 ALDENVSVESVAKPIPEYTSVVSLLGLGVMGASSLLTRQQKLVKK -...- 359 ALDPNVNVESVTKPIPEYTSVVSLLGLGVIGASSLLTRKOKSVIK-...-- 340 QLDPHVEFQGTVQ- 325 DLDRHVDLEREISAIEAGEGSKL_... 337 ** :* 


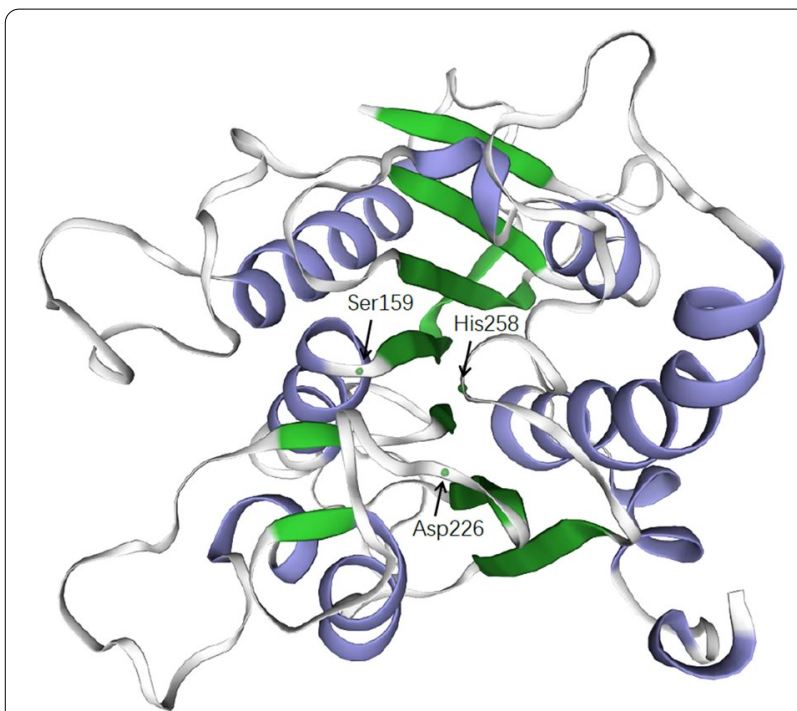

Fig. 2 Predicted tertiary structure of OaCLH. This diagram was constructed with the SWISS-MODEL server. The conserved catalytic triad residues (Ser159, Asp226, and His258) of OaCLH are indicated

Previous studies have shown that the $\mathrm{N}$-terminal transit peptide of chlorophyllase plays an important role in its Chl hydrolysis activity. Chen et al. reported that the chlorophyllases from Pachira macrocarpa from which the $\mathrm{N}$-terminal transit peptide was removed were functionally inactive [19]. However, Harpaz-Saad et al. showed that the removal of the N-terminal 21 amino acids of chlorophyllase from Citrus sinensis generated a more active enzyme in vivo [27]. The presence of a putative 28-amino-acid signal peptide was predicted at the $\mathrm{N}$-terminal end of the OaCLH sequence. The TMpred server also predicted that the amino acid sequence from Leu 10 to Met 29 is an N-terminally located transmembrane domain, which could anchor OaCLH within the thylakoid membrane, in which the cyanobacterial chlorophylls localize. To evaluate the role of the predicted $\mathrm{N}$-terminal signal peptide in the activity of recombinant $\mathrm{OaCLH}$, an in vitro chlorophyllase activity assay was performed using purified full-length and $\mathrm{N}$-terminally truncated OaCLHs and Chl a as the substrate. The results (Fig. 5) indicated that full-length OaCLH displayed significantly higher specific chlorophyllase activity than truncated $\mathrm{OaCLH}$. The removal of the predicted signal peptide sequence caused more than 95\% activity loss in OaCLH. Therefore, the predicted $\mathrm{N}$-terminal signal peptide sequence of recombinant $\mathrm{OaCLH}$ is essential for its activity.
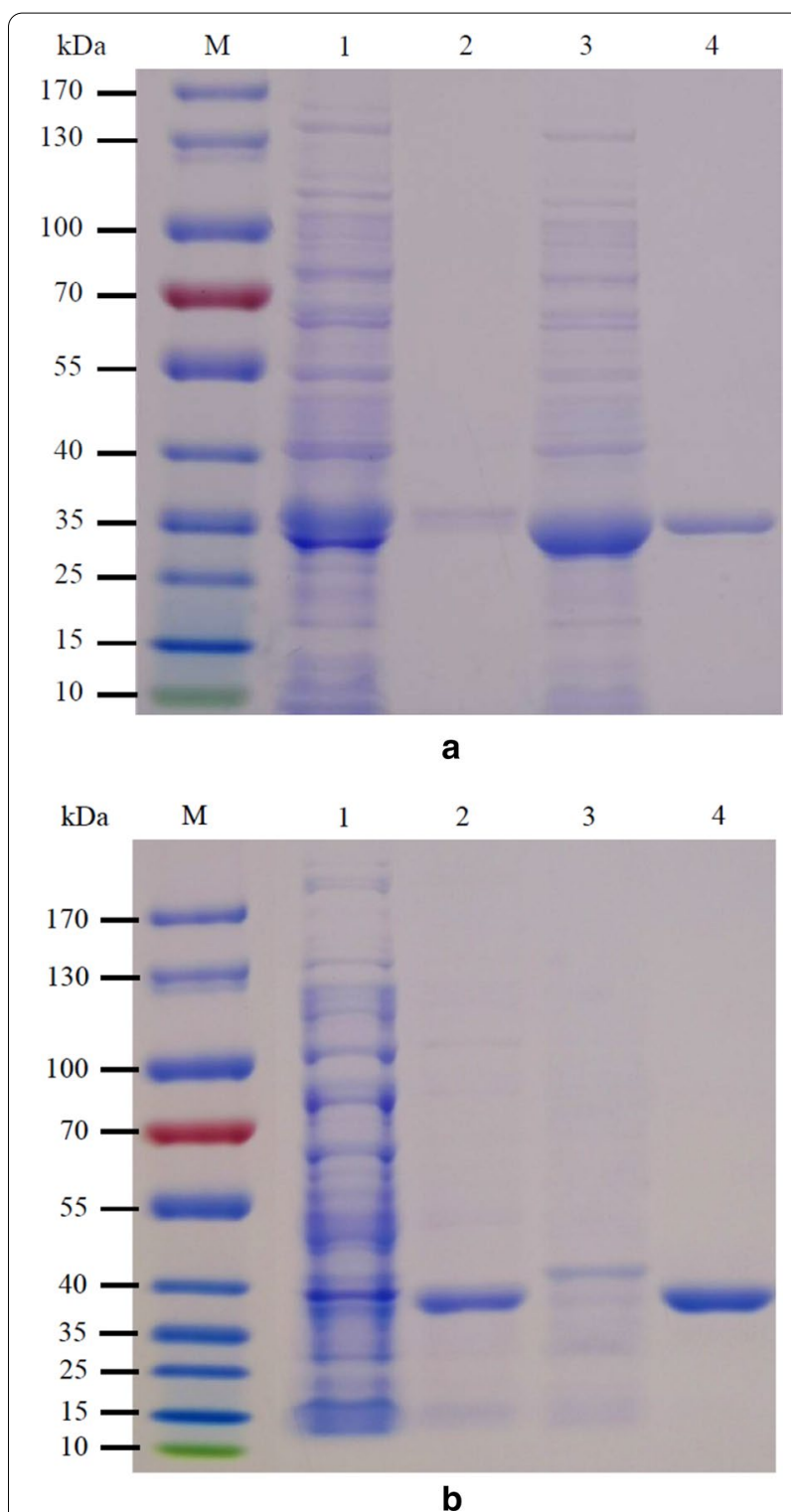

Fig. 3 a SDS-PAGE analysis of C-terminally $6 \times$ His-tagged recombinant $\mathrm{OaCLH}$ s. M, prestained molecular weight marker. Lane 1, crude extract of recombinant full-length OaCLH. Lane 2, purified recombinant full-length $\mathrm{OaCLH}$ after $\mathrm{Ni}^{2+}$ affinity chromatography. Lane 3, crude extract of recombinant truncated OaCLH. Lane 4, purified recombinant truncated $\mathrm{OaCLH}$ after $\mathrm{Ni}^{2+}$ affinity chromatography. The protein gel was stained with Coomassie Brilliant Blue

b SDS-PAGE analysis of N-terminally $6 \times$ His-tagged recombinant OaCLHs. M, prestained molecular weight marker. Lane 1, crude extract of recombinant full-length OaCLH. Lane 2, crude extract of recombinant truncated OaCLH. Lane 3, purified recombinant full-length $\mathrm{OaCLH}$ after $\mathrm{Ni}^{2+}$ affinity chromatography. Lane 4, purified recombinant truncated $\mathrm{OaCLH}$ after $\mathrm{Ni}^{2+}$ affinity chromatography. The protein gel was stained with Coomassie Brilliant Blue 


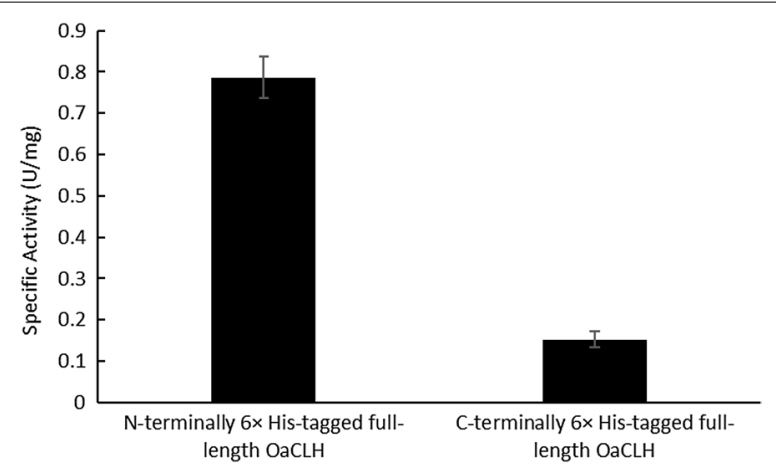

Fig. 4 Effect of $\mathrm{N}$-terminal and C-terminal fusion with a $6 \times$ His tag on the activity of recombinant full-length $\mathrm{OaCLH}$. Specific activities of purified N-terminally and C-terminally $6 \times$ His-tagged full-length $\mathrm{OaCLH}$ were measured with the standard chlorophyllase activity assay method, using Chl a as the substrate. The Bradford method was used to quantify the protein. Values are the means \pm standard deviation (SD) of three independent experiments

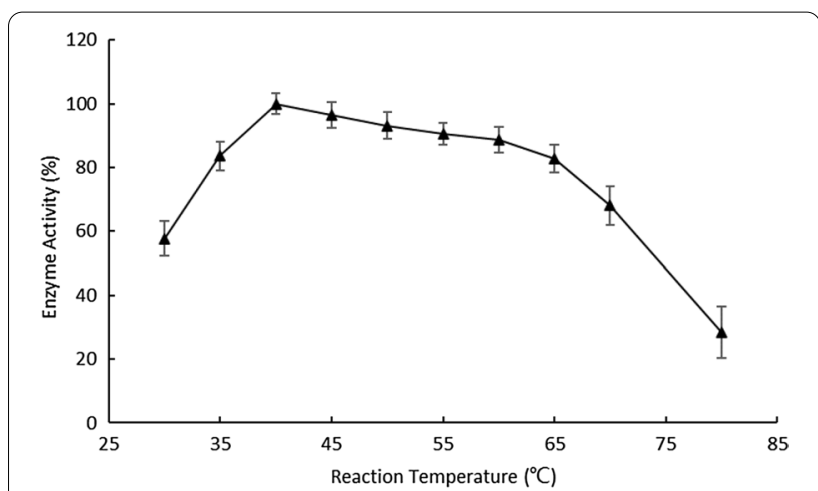

Fig. 6 Effect of temperature on the activity of recombinant OaCLH. The optimal temperature of recombinant $\mathrm{OaCLH}$ was measured with the standard chlorophyllase activity assay method, using Chl a as the substrate. Values are the means \pm SD of three independent experiments

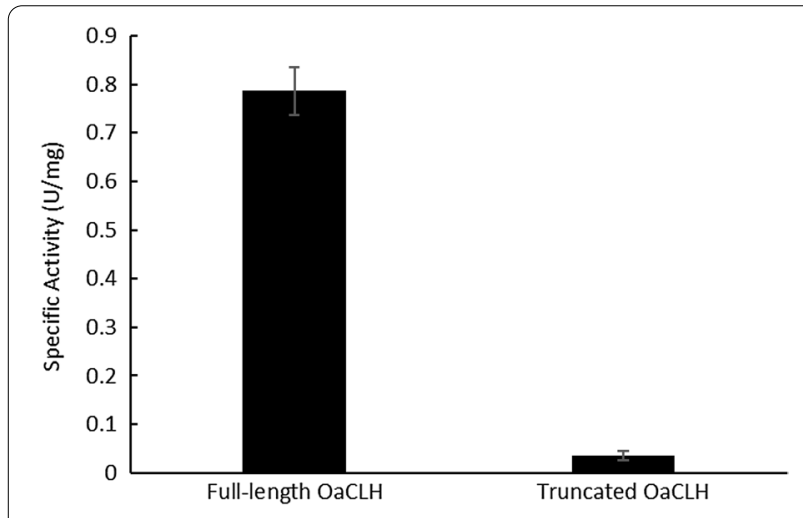

Fig. 5 Effect of the predicted N-terminal signal peptide on the activity of recombinant $\mathrm{OaCLH}$. Specific activities of purified full-length and truncated $\mathrm{OaCLHs}$ were measured with the standard chlorophyllase activity assay method, using Chl a as the substrate. The Bradford method was used to quantify the protein. Values are the means \pm SD of three independent experiments

The biochemical characterization and kinetics of purified $\mathrm{N}$-terminally $6 \times$ His-tagged full-length $\mathrm{OaCLH}$ were investigated in this work.

\section{Biochemical characterization of recombinant $\mathrm{OaCLH}$}

The recombinant $\mathrm{OaCLH}$ had an optimal temperature for $\mathrm{Chl}$ a hydrolysis of $40^{\circ} \mathrm{C}$, and maintained $>80 \%$ of its peak activity in a temperature range of $35-65^{\circ} \mathrm{C}$. However, more than $70 \%$ of its chlorophyllase activity was lost when the reaction temperature reached $80^{\circ} \mathrm{C}$ (Fig. 6). Khalyfa et al. reported that the optimum temperature range for chlorophyllase activity is $25-37^{\circ} \mathrm{C}$, and the optimum reaction temperature for

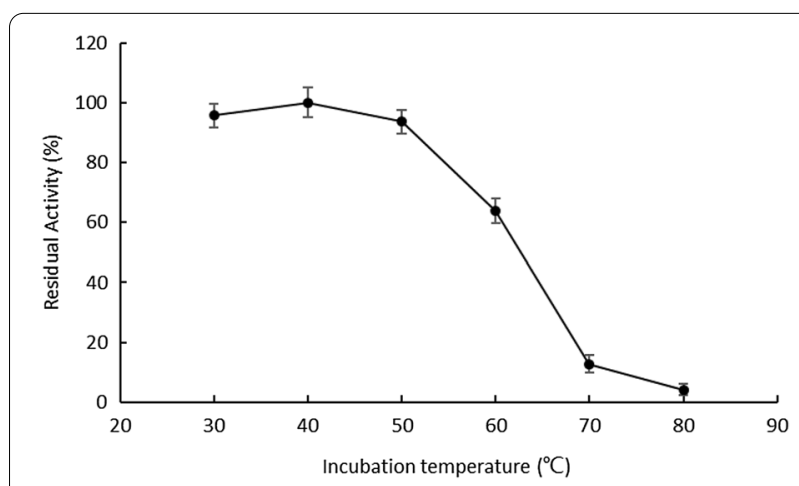

Fig. 7 Effect of temperature on the thermal stability of recombinant $\mathrm{OaCLH}$. The residual activities of recombinant OaCLH were measured with the standard chlorophyllase activity assay method, using $\mathrm{Chl}$ $a$ as the substrate. Values are the means \pm SD of three independent experiments

Pheaodactylumn tricornutum chlorophyllase is $31^{\circ} \mathrm{C}$ [12]. Chou et al. demonstrated that the optimum temperatures for the catalytic activities of chlorophyllase 1 from Chlamydomonas reinhardtii and chlorophyllase from Cyanothece sp. ATCC 51142 were $40^{\circ} \mathrm{C}$ and $60^{\circ} \mathrm{C}$, respectively $[22,23]$.

The recombinant $\mathrm{OaCLH}$ remained stable at 30 , 40 , and $50^{\circ} \mathrm{C}$. After incubation for $60 \mathrm{~min}$ at 30,40 , or $50^{\circ} \mathrm{C}$, more than $90 \%$ of its catalytic activity was retained. When the incubation temperature increased to $60^{\circ} \mathrm{C}$, the residual activity was approximately $64 \%$ after incubation for $60 \mathrm{~min}$. After incubation for $60 \mathrm{~min}$ at $70^{\circ} \mathrm{C}$ and $80^{\circ} \mathrm{C}$, only $13 \%$ and $4 \%$ of its activity remained, respectively (Fig. 7).

The optimal $\mathrm{pH}$ of the recombinant $\mathrm{OaCLH}$ for Chl a hydrolysis is 7.0 , and about $90 \%$ of its peak activity was 


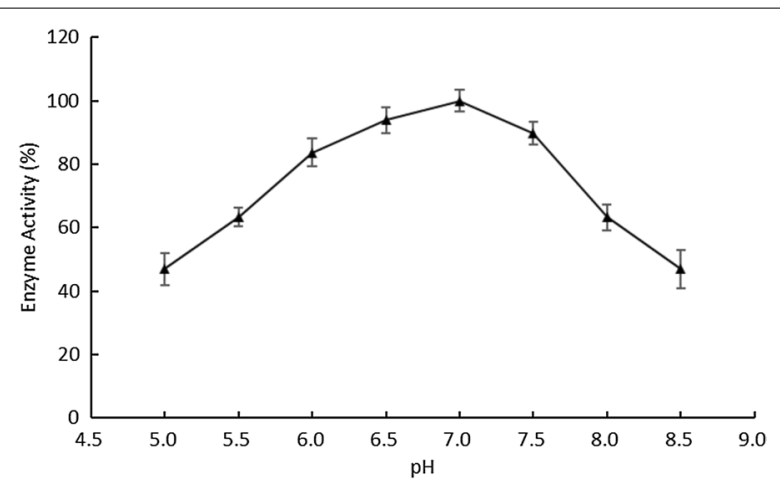

Fig. 8 Effect of $\mathrm{pH}$ on the activity of recombinant OaCLH. The optimal $\mathrm{pH}$ of recombinant $\mathrm{OaCLH}$ was measured with the standard chlorophyllase activity assay method, using $\mathrm{Chl}$ a as the substrate. Values are the means \pm SD of three independent experiments

detected at pH 6.5 and pH 7.5 (Fig. 8). These results agree well with the fact that most chlorophyllases from various sources have optimal $\mathrm{pHs}$ close to neutrality, as previously reported by Tsuchiya et al. [8]. Chou et al. also reported that the optimal catalytic activity of chlorophyllase from Cyanothece sp. ATCC 51142 occurred at $\mathrm{pH} 7.0$ [23].

The recombinant $\mathrm{OaCLH}$ was stable in the $\mathrm{pH}$ range of 5.0-8.0. After incubation for $40 \mathrm{~h}$ at $\mathrm{pH} 5.0$, its residual activity was $90 \%$. After incubation for $40 \mathrm{~h}$ at $\mathrm{pH} 5.5,6.0$, $6.5,7.0,7.5$, or 8.0 , more than $95 \%$ of its catalytic activity was retained. However, when the incubation $\mathrm{pH}$ was increased to 8.5 , only $69 \%$ of its catalytic activity remained (Fig. 9).

\section{Enzyme kinetics of recombinant $\mathrm{OaCLH}$}

To investigate the kinetic parameters and substrate specificity of recombinant $\mathrm{OaCLH}$, the initial reaction

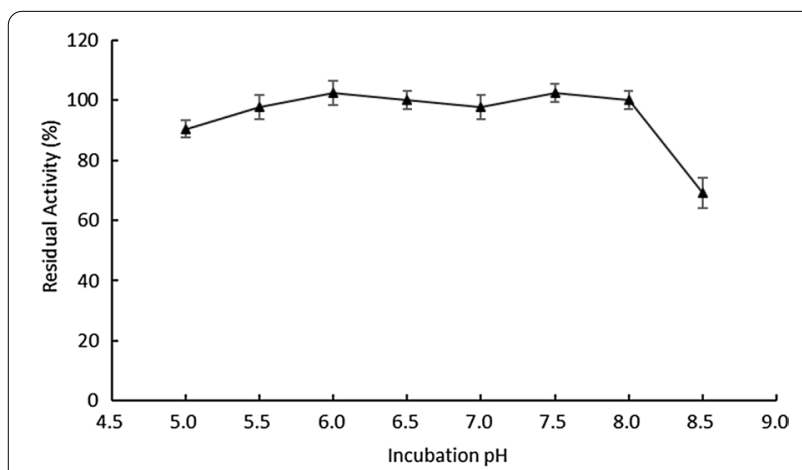

Fig. 9 Effect of $\mathrm{pH}$ on the stability of recombinant OaCLH. The residual activities of recombinant $\mathrm{OaCLH}$ were measured with the standard chlorophyllase activity assay method, using Chl a as the substrate. Values are the means \pm SD of three independent experiments velocities $\left(\mathrm{V}_{0}\right)$ of full-length recombinant OaCLH toward different concentrations of four substrates $(\mathrm{Chl} \mathrm{a}, \mathrm{Chl} b$, $\mathrm{BChl} \mathrm{a}$, and Phe a) were determined.

Table 2 summarizes the kinetic parameters of recombinant $\mathrm{OaCLH}$ : maximal velocity $\left(\mathrm{V}_{\max }\right)$, Michaelis constant $\left(\mathrm{K}_{\mathrm{m}}\right)$, catalytic activity $\left(\mathrm{k}_{\text {cat }}\right)$, and catalytic efficiency $\left(\mathrm{k}_{\text {cat }} / \mathrm{K}_{\mathrm{m}}\right)$. These results show that Chl a, Chl b, BChl $\mathrm{a}$, and Phe a are all reaction substrates of the recombinant $\mathrm{OaCLH}$. The catalytic efficiency of the recombinant $\mathrm{OaCLH}$ was similar to those of chlorophyllase 1 $\left(15.51 \times 10^{-5} \mathrm{~s}^{-1} \mu \mathrm{M}^{-1}, \mathrm{Chl}\right.$ a) and chlorophyllase 2 $\left(0.78 \times 10^{-5} \mathrm{~s}^{-1} \mu \mathrm{M}^{-1}\right.$, Chl a) of Brassica oleracea [21]. Recombinant $\mathrm{OaCLH}$ had the highest catalytic efficiency $\left(\mathrm{k}_{\text {cat }} / \mathrm{K}_{\mathrm{m}}\right)$ for Chl b $\left(6.80 \times 10^{-5} \mathrm{~s}^{-1} \mu \mathrm{M}^{-1}\right)$, followed by Chl a $\left(3.2 \times 10^{-5} \mathrm{~s}^{-1} \mu \mathrm{M}^{-1}\right)$, and the lowest catalytic efficiency for BChl a $\left(1.20 \times 10^{-5} \mathrm{~s}^{-1} \mu \mathrm{M}^{-1}\right)$ and Phe a $\left(1.19 \times 10^{-5} \mathrm{~s}^{-1} \mu \mathrm{M}^{-1}\right)$. Therefore, recombinant $\mathrm{OaCLH}$ preferentially hydrolyzes $\mathrm{Chl} b$ and $\mathrm{Chl}$ a over $\mathrm{BChl}$ a and Phe a, which is consistent with the preferences of both plant and algal chlorophyllases [28, 29]. However, Chou et al. reported that recombinant CyanoCLH from the cyanobacterium Cyanothece sp. ATCC 51472 preferentially hydrolyzes $\mathrm{BChl}$ a to produce $\mathrm{BChlide}$ a [23]. Sharafi et al. also predicted that all bacterial and cyanobacterial chlorophyllases prefer $\mathrm{BChl}$ a as their substrate $[24,30]$. Therefore, this is the first report of a cyanobacterial chlorophyllase with a substrate preference for $\mathrm{Chl}$ $\mathrm{a}$ and $\mathrm{Chl} \mathrm{b}$ rather than $\mathrm{BChl}$ a. Furthermore, although recombinant $\mathrm{OaCLH}$ preferentially hydrolyzes $\mathrm{Chl} b$ and Chl a, it also shows good catalytic efficiency $\left(\mathrm{k}_{\mathrm{cat}} / \mathrm{K}_{\mathrm{m}}\right)$ for $\mathrm{BChl}$ a and Phe a (Table 2). Therefore, recombinant $\mathrm{OaCLH}$ has broad substrate specificity.

\section{Identification of the putative catalytic triad}

A multiple sequence alignment of cyanobacterial chlorophyllases is an effective way to predict the active-site residues, because these residues are conserved well across these amino acid sequences. In this study, the amino acid sequence of OaCLH was aligned with eight previously reported cyanobacterial chlorophyllase sequences. The alignment showed that Ser159, Asp226, and His258 are strictly conserved in all cyanobacterial chlorophyllases

Table 2 Substrate specificity and kinetic parameters of recombinant $\mathrm{OaCLH}$

\begin{tabular}{|c|c|c|c|c|}
\hline Substrate & $\begin{array}{l}\mathrm{V}_{\max } \\
\left(10^{-3} \mu \mathrm{mol}\right. \\
\left.\mathrm{mg}^{-1} \min ^{-1}\right)\end{array}$ & $K_{m}(\mu M)$ & $\mathrm{K}_{\text {cat }}\left(10^{-3} \mathrm{~s}^{-1}\right)$ & $\begin{array}{l}\mathrm{K}_{\mathrm{cat}} / \mathrm{K}_{\mathrm{m}} \\
\left(10^{-5} \mathrm{~s}^{-1}\right. \\
\left.\mu \mathrm{M}^{-1}\right)\end{array}$ \\
\hline Chla & 0.98 & 20.41 & 0.65 & 3.20 \\
\hline $\mathrm{Chl} \mathrm{b}$ & 2.13 & 20.92 & 1.42 & 6.80 \\
\hline BChl a & 16.03 & 888.10 & 10.68 & 1.20 \\
\hline Phe a & 2.91 & 162.95 & 1.94 & 1.19 \\
\hline
\end{tabular}


and may therefore be the putative catalytic triad of $\mathrm{OaCLH}$.

All members of the $\alpha / \beta$ hydrolase family contain a catalytic triad consisting of a nucleophile, a base, and an orientating acid [31]. Serine is responsible for the nucleophilic attack on the carbonyl carbon of the scissile ester bond. This serine lies in the consensus sequence glycine (Gly)-X-Ser-X-Gly, which is conserved in most esterases and lipases [32]. Therefore, Ser159 is a likely member of the catalytic triad of OaCLH. The catalytic histidine acts as a general base during the catalysis reactions of the $\alpha / \beta$ hydrolase family. A rule of thumb for identifying histidine as a member of the catalytic triad is that it should be located after the final central parallel $\beta$-sheet [33]. According to this rule, His258 may be one of the active-site residues that form the catalytic triad. The catalytic aspartic acid residue acts as an orientating acid and is usually located between the catalytic serine and histidine. Therefore, Asp226 may be a component of the catalytic triad.

Some site-directed mutation studies have demonstrated the importance of the catalytic triad (Ser-AspHis) for chlorophyllase activity. Tsuchiya et al. showed that the catalytic triad (Ser162, Asp191, His262) of Chenopodium album chlorophyllase is essential for its enzymatic activity [17]. Lee et al. reported that three Brassica oleracea chlorophyllase 2 (BoCLH2) mutants, in each of which one catalytic residue (Ser141, Asp170, or His247) was replaced with alanine, had either reduced or no chlorophyllase activity [21].

We constructed the mutant enzymes S159A, D226N, and $\mathrm{H} 258 \mathrm{~A}$ with site-directed mutagenesis to identify the roles of these putative catalytic residues in OaCLH. Asp226 was substituted with asparagine (Asn) to minimize any conformational change caused by the mutation. Asp224 was also replaced with Asn to identify its function during catalysis because it is close to the putative catalytic residue Asp226.

As shown in Table 3, the mutation S159A or H258A caused the complete loss of activity, indicating that these residues are essential for the catalytic activity of OaCLH. The mutant enzyme D226N had a much lower specific activity (21\% relative specific activity) than the wild-type enzyme. The D226N mutant was not completely inactivated because the catalytic Asp residue plays an auxiliary role in catalysis. The specific activity of mutant enzyme D224N was $24 \%$ higher than that of the wild-type enzyme. Therefore, Asp224 is not a catalytic residue of $\mathrm{OaCLH}$. As mentioned above, the catalytic Asp residue acts as an orientating acid, and its ionized carboxyl group is required to stabilize the protonated form of the imidazole group of the catalytic His residue [34]. Because it is close to the putative catalytic residue Asp226, Asp224 is
Table 3 Specific activities and relative activities of purified wild-type and mutated $\mathrm{OaCLH}$. The relative specific activity of wild-type $\mathrm{OaCLH}$ was deemed to be $100 \%$

\begin{tabular}{lcc}
\hline Name of mutant & $\begin{array}{l}\text { Specific activity (mU/ } \\
\mathbf{m g})\end{array}$ & $\begin{array}{l}\text { Relative } \\
\text { specific } \\
\text { activity (\%) }\end{array}$ \\
\hline Wild-type & 786 & 100 \\
S159A & 0 & 0 \\
D224N & 975 & 124 \\
D226N & 165 & 21 \\
H258A & 0 & 0 \\
\hline
\end{tabular}

likely to interact with catalytic residue His258 and form another catalytic triad with catalytic residues Ser159 and His 258 . This could lead to the instability of the catalytic active center and a partial loss of activity. Asparagine (Asn) has no carboxyl group, so it cannot interact with catalytic His 258 and form the catalytic triad. Therefore, the mutant enzyme D224N contains just one stable catalytic triad and showed higher specific activity than the wild-type enzyme. In summary, the results of these site-directed mutagenesis experiments suggest that the catalytic triad of OaCLH consists of Ser159, Asp226, and His258.

\section{Conclusions}

A novel recombinant OaCLH was successfully expressed in E. coli BL21(DE3). The catalytic triad of OaCLH consists of Ser159, Asp226, and His258. The putative N-terminal 28-amino-acid signal peptide sequence of $\mathrm{OaCLH}$ is essential for its chlorophyllase activity, but might confer poor solubility on OaCLH. Its C-terminal fusion with a $6 \times$ His tag caused the partial activity loss of recombinant $\mathrm{OaCLH}$, but an $\mathrm{N}$-terminal $6 \times$ His tag did not destroy its activity. Recombinant OaCLH hydrolyzes Chl a, Chl b, BChl a, and Phe a, but preferentially uses Chl b and $\mathrm{Chl}$ a as substrates. Therefore, the strong expression and broad substrate specificity of recombinant $\mathrm{OaCLH}$ makes it a good candidate enzyme for genetic engineering. It may also be a promising biocatalyst for industrial production, with applications in vegetable oil refining and laundry detergents.

\section{Materials and methods}

Strains, plasmids and chemicals

Escherichia coli BL21(DE3) (Invitrogen, Carlsbad, CA, USA), and plasmids pET-24a(+) and pET-28a(+) (Novagen, Darmstadt, Germany) were used for gene expression. The Universal DNA Purification Kit and Midi Plasmid kit were purchased from Omega Bio-tek (Norcross, GA, USA) or Tiangen (Beijing, China). DNA polymerase 
$(K O D)$ was purchased from TOYOBO (Osaka, Japan). All restriction endonucleases were purchased from New England BioLabs (Ipswich, MA, USA). T4 DNA ligase was purchased from Thermo Fisher Scientific (Waltham, MA, USA). The substrates chlorophyll a (from spinach), chlorophyll b (from spinach), and bacteriochlorophyll a (from Rhodopseudomonas sphaeroides) were purchased from Sigma (St. Louis, MO, USA). The substrate pheophytin a was purchased from Wako Pure Chemical industries, Ltd (Osaka, Japan).

\section{Sequence analysis}

The putative protein sequence of $O$. acuminata chlorophyllase (OaCLH, GenBank accession no. AFY81906.1) was obtained from the NCBI database. The molecular weight, theoretical pI, estimated half-life, instability index, aliphatic index, and GRAVY value of OaCLH were predicted with the ProtParam tool (https://web.expas y.org/protparam/). The putative OaCLH sequence was also analyzed with programs TargetP-2.0 server (http:// www.cbs.dtu.dk/services/TargetP/), SignalP 5.0 server (http://www.cbs.dtu.dk/services/SignalP/), and TMpred server (https://embnet.vital-it.ch/software/TMPRED_ form.html) [35-38].

A multiple sequence alignment of the putative $O$. acuminata chlorophyllase and eight other published cyanobacterial chlorophyllases was constructed with Clustal Omega (https://www.ebi.ac.uk/Tools/msa/clust alo/). A homology structural model of OaCLH was constructed with the SWISS-MODEL server (https://swiss model.expasy.org). The SAVES v5.0 server was used to verify and validate the three-dimensional structure of OaCLH (https://servicesn.mbi.ucla.edu/SAVES/).

\section{Heterologous expression of OaCLH in E. coli}

The nucleotide sequence of the $O a C L H$ gene was codon optimized for $E$. coli expression. The endonuclease sites NdeI and XhoI were introduced at the $5^{\prime}$ - and $3^{\prime}$-termini of the target gene, respectively, to allow the insertion of the target gene into the expression plasmids pET-24a $(+)$ and pET-28a $(+)$. The oligonucleotides and the codonoptimized $\mathrm{OaCLH}$ gene (full-length version and signalpeptide-sequence-truncated version) were synthesized by Shanghai Sangon Biotech Co. Ltd (China).

The synthesized DNA fragments were digested with NdeI and XhoI and ligated into pET-24a(+) and pET$28 \mathrm{a}(+)$ digested with the same enzymes to construct an in-frame $\mathrm{C}$-terminal or $\mathrm{N}$-terminal fusion protein with a $6 \times$ His tag sequence. Competent $E$. coli BL21(DE3) cells were transformed with the resulting constructs $\mathrm{pET}$ $24 \mathrm{a}(+)-O a C L H$ and $\mathrm{pET}-28 \mathrm{a}(+)-O a C L H$ and the transformants were selected on Luria-Bertani (LB) medium plates containing $50 \mu \mathrm{g} / \mathrm{mL}$ kanamycin.
The cells carring the recombinant plasmid pET$24 \mathrm{a}(+)-O a C L H$ or $\mathrm{pET}-28 \mathrm{a}(+)-O a C L H$ were grown aerobically at $37^{\circ} \mathrm{C}$ in liquid $\mathrm{LB}$ medium containing $50 \mu \mathrm{g} / \mathrm{mL}$ kanamycin until the optical density at a wavelength of $600 \mathrm{~nm}$ reached $0.6-0.8$. The expression of the recombinant $\mathrm{OaCLHs}$ was then induced by the addition of IPTG at a final concentration of $0.1 \mathrm{mM}$ and incubation for $16 \mathrm{~h}$ at $20^{\circ} \mathrm{C}$.

The recombinant-OaCLH-expressing cells were harvested by centrifugation at $10,000 \times \mathrm{g}$ for $10 \mathrm{~min}$ at $4{ }^{\circ} \mathrm{C}$. The cell pellets were then resuspended in lysis buffer $(100 \mathrm{mM}$ sodium phosphate, $\mathrm{pH} 7.0)$ and disrupted by ultrasonication in an ice bath. After centrifugation $\left(10,000 \times \mathrm{g}\right.$ for $15 \mathrm{~min}$ at $\left.4^{\circ} \mathrm{C}\right)$, the supernatant was used as a crude extract of recombinant $\mathrm{OaCLH}$. The supernatant was analyzed with chlorophyllase activity assays and SDS-PAGE. The total soluble protein content was measured with the Bradford method using bovine serum albumin as the standard [39].

\section{Enzyme purification}

To purify of the recombinant protein, the crude enzyme was dialyzed against binding buffer $(20 \mathrm{mM}$ sodium phosphate, $0.5 \mathrm{M} \mathrm{NaCl}, 20 \mathrm{mM}$ imidazole, $\mathrm{pH} 7.4$ ) and the enzyme solution was then applied to a HisTrap HP $5 \mathrm{~mL}$ column (GE Healthcare, Uppsala, Sweden) previously equilibrated with binding buffer. Any unbound protein was washed out with 10 column volumes $(\mathrm{CVs})$ of binding buffer. The $6 \times$ His-tagged protein was eluted with $5 \mathrm{CVs}$ of elution buffer $(20 \mathrm{mM}$ sodium phosphate, $0.5 \mathrm{M} \mathrm{NaCl}, 500 \mathrm{mM}$ imidazole, $\mathrm{pH}$ 7.4). The enzyme fractions were pooled, concentrated with an Amicon Ultra-15 Centrifugal Filter with $10 \mathrm{kDa}$ cut-off (Millipore, USA) and dialyzed against lysis buffer. The purified enzyme was analyzed with a chlorophyllase activity assay and SDS-PAGE. The protein content was measured with the Bradford method using bovine serum albumin as the standard.

\section{Chlorophyllase activity assay}

Chlorophyllase activity was measured with a modified method described by Lee et al. [21]. The reaction mixture contained $100 \mu \mathrm{L}$ of enzyme, $220 \mu \mathrm{L}$ of reaction buffer (100 mM sodium phosphate, $\mathrm{pH} 7.0$ ), $40 \mu \mathrm{L}$ of substrate $(1000 \mu \mathrm{M}$, dissolved in acetone), and $40 \mu \mathrm{L}$ of acetone. The reaction mixture was incubated at $40^{\circ} \mathrm{C}$ in the dark for $30 \mathrm{~min}$. The reaction was then quenched by the addition of $400 \mu \mathrm{L}$ of $10 \mathrm{mM} \mathrm{KOH}, 1600 \mu \mathrm{L}$ of acetone, and $2400 \mu \mathrm{L}$ of $\mathrm{n}$-hexane. The mixture was vigorously vortexed and centrifuged at $10,000 \times \mathrm{g}$ for $5 \mathrm{~min}$. Two separate phases were obtained. The upper $\mathrm{n}$-hexane phase contained the unreacted substrate $\mathrm{Chl}$ a, $\mathrm{Chl} b, \mathrm{BChl} \mathrm{a}$, 
or Phe a. The lower aqueous acetone phase contained the reaction product Chlide a, Chlide b, BChlide a, or Pheide a.

The amount of product was calculated from the absorbance of the aqueous acetone phase, which was measured at $665 \mathrm{~nm}$ for Chlide a, $650 \mathrm{~nm}$ for Chlide b, $773 \mathrm{~nm}$ for BChlide a, and $667 \mathrm{~nm}$ for Pheide a [28, 40]. The millimolar extinction coefficients are $54.1 \mathrm{mM}^{-1} \mathrm{~cm}^{-1}$ for Chlide a, $42.0 \mathrm{mM}^{-1} \mathrm{~cm}^{-1}$ for Chlide b, $42.1 \mathrm{mM}^{-1} \mathrm{~cm}^{-1}$ for BChlide a, and $47.2 \mathrm{mM}^{-1} \mathrm{~cm}^{-1}$ for Pheide a $[28,40]$. One unit of enzyme activity was defined as the amount of enzyme required to catalyze the production of $1 \mathrm{nmol}$ Chlide a, Chlide b, BChlide a, or Pheide a per minute at $40^{\circ} \mathrm{C}$. The specific activity of the enzyme was defined as the enzyme activity (units) per milligram of protein. All enzymatic assays were performed in triplicate. Control reactions, in which the enzyme was replaced with distilled water, were performed at the same temperatures, $\mathrm{pHs}$, and other conditions as the chlorophyllase activity assays to ensure that there was no spontaneous substrate hydrolysis.

\section{Biochemical characterization of recombinant $\mathrm{OaCLH}$}

Purified recombinant $\mathrm{OaCLH}$ was biochemically characterized by measuring its hydrolysis activity against $\mathrm{Chl}$ a.

The optimal temperature of $\mathrm{OaCLH}$ for Chl a hydrolysis was determined to be $30-80^{\circ} \mathrm{C}$, according to the chlorophyllase activity assay described above. To investigate its thermal stability, enzyme samples were incubated for $60 \mathrm{~min}$ at temperatures ranging from 30 to $80^{\circ} \mathrm{C}$ and then cooled to $4{ }^{\circ} \mathrm{C}$. The residual activities of the enzyme samples were measured with the chlorophyllase activity assay described above.

The optimal $\mathrm{pH}$ was measured using $100 \mathrm{mM}$ sodium acetate buffer (pH 5.0 or 5.5$), 100 \mathrm{mM}$ sodium phosphate buffer (pH 6.0, 6.5, 7.0, or 7.5) and $100 \mathrm{mM}$ Tris- $\mathrm{HCl}$ buffer ( $\mathrm{pH} 8.0$ or 8.5 ). The enzyme reaction was performed with the standard assay method.

To analyze the stability of $\mathrm{OaCLH}$ at various $\mathrm{pHs}$, enzyme solutions were dialyzed against different buffers (pH 5.0-8.5), as described above, and then incubated for $40 \mathrm{~h}$ at $4{ }^{\circ} \mathrm{C}$. The residual activities were then measured with the standard assay method.

The highest activity was taken as $100 \%$, and the percentages of the other activities were calculated relative to the highest activity. All reactions were performed in triplicate.

\section{Determination of enzyme kinetic parameters}

Kinetic assays of purified recombinant $\mathrm{OaCLH}$ were performed for $30 \mathrm{~min}$ at $40^{\circ} \mathrm{C}$ with a spectrophotometer. The initial reaction velocity $\left(\mathrm{V}_{0}\right)$ was determined with different concentrations of substrates $(10-100 \mu \mathrm{M}$ Chl a, $10-100 \mu \mathrm{M}$ Chl b, 50-500 $\mu \mathrm{M}$ BChl a, and
Table 4 Oligonucleotide primers used for site-directed mutagenesis. Mutations introduced are shown in bold. $\mathrm{Ndel}$ and $\mathrm{Xhol}$ restriction sites are underlined

\begin{tabular}{ll}
\hline Primers & Oligonucleotides sequences \\
\hline OaCLH-F & 5'-CATATGAGCGTTATCTCTCGTCACTCTAGC-3' \\
OaCLH-R & 5'-CTCGAGTTACTGAACGGTCTGGCCCTGAAA-3' \\
S159A & 5'-TCTGCTGGGTCACGCTTGGGGTGGCGCGG-3' \\
D224N & 5'-GGCCTGATCGCGGGTAATCGTGATGGCGTT-3' \\
D226N & 5'-TCGCGGGTGATCGTAATGGCGTTATCCAGG-3' \\
H258A & 5'-TTCGTGGCGCTAACGCTTACGGTATCACCA-3' \\
\hline
\end{tabular}

$50-500 \mu \mathrm{M}$ Phe a) in reaction buffer $(100 \mathrm{mM}$ sodium phosphate, $\mathrm{pH}$ 7.0). The production of Chlide a, Chlide $\mathrm{b}, \mathrm{BChlide} \mathrm{a}$, and Pheide a was measured as the maximum absorbance of each product (measured at 665, 650,773 , and $667 \mathrm{~nm}$, respectively). The kinetic parameters $\mathrm{V}_{\max }$ and $\mathrm{K}_{\mathrm{m}}$ were calculated with a nonlinear regression method using the Michaelis-Menten equation. All assays were performed in triplicate.

\section{Identification of the putative catalytic triad}

The mutant enzymes S159A, D224N, D226N, and $\mathrm{H} 258 \mathrm{~A}$ were constructed to identify the role of these putative catalytic residues in the activity of OaCLH. The desired mutations were introduced into plasmid pET$28 \mathrm{a}(+)-\mathrm{OaCLH}$ with site-directed mutagenesis using the PCR overlap extension method. The primers listed in Table 4 were designed to introduce the desired mutations. All the primers were synthesized by Shanghai Sangon Biotech Co. Ltd (China). DNA sequencing was used to confirm the veracity of the genes encoding the mutant enzymes. The recombinant strains were constructed by transforming E. coli BL21(DE3) cells with the pET-28a $(+)-O a C L H$ derivatives, into which the desired mutations had been introduced. The culture of these transformants and the expression and purification of the mutant enzymes were performed as described above for the wild-type enzyme. The enzyme reactions were performed with the standard assay method. The protein content was measured with the Bradford method using bovine serum albumin as the standard.

\section{Abbreviations \\ Chl: Chlorophyll; Chlase: Chlorophyllase; OaCLH: Oscillatoria acuminata chlorophyllase; Chl a: Chlorophyll a; Chl b: Chlorophyll b; BChl a: Bacteriochlo- rophyll a; Phe a: Pheophytin a; Chlide: Chlorophyllide; Chlide a: Chlorophyllide a; Chlide b: Chlorophyllide b; BChlide a: Bacteriochlorophyllide a; Pheide a: Pheophorbide a; IPTG: Isopropyl- $\beta$-D-thiogalactopyranoside.}

\section{Acknowledgements}

We thank Associate Prof. Song Liu (National Engineering Laboratory for Cereal Fermentation Technology, Jiangnan University) for revising this manuscript. 


\section{Authors' contributions}

Sitian Gu, Qiwen Niu, and Yuanfa Liu designed the research; Sitian Gu and Xiaojun Dai performed the experiments; Sitian Gu, Zhengjun Xu, and Jiang Jiang analyzed data; Sitian Gu was a major contributor in writing the manuscript. All authors read and approved the final manuscript.

\section{Funding}

This work was supported by National Natural Science Foundation of China (32071474 and 31771913).

\section{Availability of data and materials}

All data generated or analysed during this study are included in this published article.

\section{Ethics approval and consent to participate}

Not applicable.

\section{Consent for publication}

Not applicable.

\section{Competing interests}

The authors declare that they have no competing interests.

Received: 25 September 2020 Accepted: 29 December 2020

Published online: 12 January 2021

\section{References}

1. Hörtensteiner S, Krautler B. Chlorophyll breakdown in higher plants. Biochim Biophys Acta. 2011;1807:977-88.

2. Yi YY, Kermasha S, L'Hocine L, Neufeld R. Encapsulation of chlorophyllase in hydrophobically modified hydrogel. J Mol Catal B Enzym. 2002;19:319-25.

3. Hsu CY, Chen YH, Chao PY, Chen CM, Hsieh LL, Hu SP. Naturally occurring chlorophyll derivatives inhibit aflatoxin B-1-DNA adduct formation in hepatoma cells. Mutation Research. 2008;657:98-104.

4. Hsu CY, Yang CM, Chen CM, Chao PY, Hu SP. Effects of chlorophyll-related compounds on hydrogen peroxide induced DNA damage within human lymphocytes. J Agric Food Chem. 2005;53:2746-50.

5. Guo HT, Pan XB, Mao RC, Zhang XC, Wang LJ, Lu XY, Chang JH, Guo JT, Passic S, Krebs FC, et al. Alkylated porphyrins have broad antiviral activity against hepadnaviruses, flaviviruses, filoviruses, and arenaviruses. Antimicrob Agents Chemother. 2011;55:478-86.

6. You H, Yoon HE, Jeong PH, Ko H, Yoon JH, Kim YC. Pheophorbide-a conjugates with cancer-targeting moieties for targeted photodynamic cancer therapy. Bioorg Med Chem. 2015;23:1453-62.

7. Della Pietra E, Simonella F, Bonavida B, Xodo LE, Rapozzi V. Repeated sub-optimal photodynamic treatments with pheophorbide a induce an epithelial mesenchymal transition in prostate cancer cells via nitric oxide. Nitric Oxide. 2015:45:43-53.

8. Tsuchiya T, Ohta H, Masuda T, Mikami B, Kita N, Shioi Y, Takamiya K. Purification and characterization of two isozymes of chlorophyllase from mature leaves of Chenopodium album. Plant Cell Physiol. 1997:38:1026-31.

9. Shemer TA, Harpaz-Saad S, Belausov E, Lovat N, Krokhin O, Spicer V, Standing KG, Goldschmidt EE, Eyal Y. Citrus chlorophyllase dynamics at ethylene-induced fruit color-break: A study of chlorophyllase expression, posttranslational processing kinetics, and in situ intracellular localization. Plant Physiol. 2008;148:108-18.

10. Nishiyama Y, Kitamura M, Tamura S, Watanabe T. Purification and substrate-specificity of chlorophyllase from Chlorella-Regularis. Chem Lett. 1994;23:69-72.

11. Khalyfa A, Kermasha S, Khamessan A, Marsot P, Alli I. Purification and characterization of chlorophyllase from alga (Phaeodactylum-Tricornutum) by preparative isoelectric-focusing. Biosci Biotechnol Biochem. 1993;57:433-7.

12. Khalyfa A, Kermasha S, Marsot P, Goetghebeur M. Purification and characterization of chlorophyllase from alga Phaeodactylum-Tricornutum by preparative native electrophoresis. Appl Biochem Biotechnol. 1995;53:11-27.
13. Takamiya K, Tsuchiya T, Ohta H. Degradation pathway(s) of chlorophyll: what has gene cloning revealed? Trends Plant Sci. 2000;5:426-31.

14. Okazawa A, Tang L, Itoh Y, Fukusaki E, Kobayashi A. Characterization and subcellular localization of chlorophyllase from Ginkgo biloba. Zeitschrift Fur Naturforschung C-a Journal of Biosciences. 2006;61:111-7.

15. Schenk N, Schelbert S, Kanwischer M, Goldschmidt EE, Dörmann P, Hörtensteiner S. The chlorophyllases AtCLH1 and AtCLH2 are not essential for senescence-related chlorophyll breakdown in Arabidopsis thaliana. Febs Lett. 2007;581:5517-25.

16. Hu X, Makita S, Schelbert S, Sano S, Ochiai M, Tsuchiya T, Hasegawa SF, Hörtensteiner S, Tanaka A, Tanaka R. Reexamination of chlorophyllase function implies its involvement in defense against chewing herbivores. Plant Physiol. 2015;167:660-70.

17. Tsuchiya T, Ohta H, Okawa K, Iwamatsu A, Shimada H, Masuda T, Takamiya K. Cloning of chlorophyllase, the key enzyme in chlorophyll degradation: finding of a lipase motif and the induction by methyl jasmonate. Proc Natl Acad Sci USA. 1999;96:15362-7.

18. Arkus KAJ, Cahoon EB, Jez JM. Mechanistic analysis of wheat chlorophyllase. Arch Biochem Biophys. 2005;438:146-55.

19. Chen MCM, Yang JH, Liu CH, Lin KH, Yang CM. Molecular, structural, and phylogenetic characterization of two chlorophyllase isoforms in Pachira macrocarpa. Plant Syst Evol. 2014;300:633-43.

20. Jacob-Wilk D, Holland D, Goldschmidt EE, Riov J, Eyal Y. Chlorophyll breakdown by chlorophyllase: isolation and functional expression of the Chlase 1 gene from ethylene-treated Citrus fruit and its regulation during development. Plant J. 1999;20:653-61.

21. Lee GC, Chepyshko H, Chen HH, Chu CC, Chou YF, Akoh CC, Shaw JF. Genes and biochemical characterization of three novel chlorophyllase isozymes from Brassica oleracea. J Agric Food Chem. 2010;58:8651-7.

22. Chou YL, Ko CY, Yen CC, Chen LFO, Shaw JF. A novel recombinant chlorophyllase 1 from Chlamydomonas reinhardtii for the production of chlorophyllide derivatives. J Agric Food Chem. 2015;63:9496-503.

23. Chou YL, Lee YL, Yen CC, Chen LFO, Lee LC, Shaw JF. A novel recombinant chlorophyllase from cyanobacterium Cyanothece sp. ATCC 51142 for the production of bacteriochlorophyllide a. Biotechnol Appl Biochem. 2016;63:371-7.

24. Sharafi E, Dehestani A, Farmani J, Parizi AP. Bioinformatics evaluation of plant chlorophyllase, the key enzyme in chlorophyll degradation. Appl Food Biotechnol. 2017;4:167-77.

25. Kuznetsova E, Proudfoot M, Sanders SA, Reinking J, Savchenko A, Arrowsmith $\mathrm{CH}$, Edwards AM, Yakunin AF. Enzyme genomics: application of general enzymatic screens to discover new enzymes. Fems Microbiol Rev. 2005;29:263-79.

26. Bollinger ATS, Knieps-Grunhagen E, Gertzen C, Kobus S, Hoppner A, Ferrer M, Gohlke H, Smits SHJ, Jaeger KE. A novel polyester hydrolase from the marine bacterium Pseudomonas aestusnigri-structural and functional insights. Front Microbiol. 2020;11:1.

27. Harpaz-Saad S, Azoulay T, Arazi T, Ben-Yaakov E, Mett A, Shiboleth YM, Hörtensteiner S, Gidoni D, Gal-On A, Goldschmidt EE, Eyal Y. Chlorophyllase is a rate-limiting enzyme in chlorophyll catabolism and is posttranslationally regulated. Plant Cell. 2007;19:1007-22.

28. Tanaka K, Kakuno T, Yamashita J, Horio T. Purification and properties of chlorophyllase from greened rye seedlings. J Biochem. 1982;92:1763-73.

29. Okazawa ATL, Itoh Y, Fukusaki E, Kobayashi A. Characterization and subcellular localization of chlorophyllase from Ginkgo biloba. Z Naturforsch C J Biosci. 2006:61:111-7.

30. Sharafi E, Farmani J, Parizi AP, Dehestani A. In search of engineered prokaryotic chlorophyllases: a bioinformatics approach. Biotechnol Bioprocess Eng. 2018;23:507-24.

31. Satoh T, Hosokawa M. The mammalian carboxylesterases: From molecules to functions. Annu Rev Pharmacol Toxicol. 1998;38:257-88

32. Brenner $\mathrm{S}$. The molecular evolution of genes and proteins: a tale of two serines. Nature. 1988;334:528-30.

33. Nardini $M$, Lang DA, Liebeton $K$, Jaeger KE, Dijkstra BM. Crystal structure of Pseudomonas aeruginosa lipase in the open conformation-The prototype for family I.1 of bacterial lipases. J Biol Chem. 2000;275:31219-25.

34. Kwon HJ, Kei A, Mitsuru H, Masaaki M, Shigenori K. Identification of the histidine and aspartic acid residues essential for enzymatic activity of a family I.3 lipase by site-directed mutagenesis. FEBS Lett. 2000;483:139-42.

35. Bendtsen JD, Nielsen $H$, von Heijne G, Brunak S. Improved prediction of signal peptides: SignalP 3.0. J Mol Biol. 2004;340:783-95. 
36. Blom N, Sicheritz-Ponten T, Gupta R, Gammeltoft S, Brunak S. Prediction of post-translational glycosylation and phosphorylation of proteins from the amino acid sequence. Proteomics. 2004;4:1633-49.

37. Gasteiger E, Gattiker A, Hoogland C, Ivanyi I, Appel RD, Bairoch A. ExPASy: the proteomics server for in-depth protein knowledge and analysis. Nucleic Acids Res. 2003;31:3784-8.

38. Nielsen H, Engelbrecht J, Brunak S, vonHeijne G. Identification of prokaryotic and eukaryotic signal peptides and prediction of their cleavage sites. Protein Eng. 1997;10:1-6.

39. M.Bradford M. A rapid and sensitive method for the quantitation of microgram quantities of protein utilizing the principle of protein-dye binding. Anal Biochem. 1976;72:248-54.
40. McFeeters RF, Chichester CO, Whitaker JR. Purification and Properties of Chlorophyllase from Ailanthus altissima (Tree-of-Heaven). Plant Physiol. 1971;47:10.

\section{Publisher's note}

Springer Nature remains neutral with regard to jurisdictional claims in published maps and institutional affiliations.
Ready to submit your research? Choose BMC and benefit from:

- fast, convenient online submission

- thorough peer review by experienced researchers in your field

- rapid publication on acceptance

- support for research data, including large and complex data types

- gold Open Access which fosters wider collaboration and increased citations

- maximum visibility for your research: over $100 \mathrm{M}$ website views per year

At BMC, research is always in progress.

Learn more biomedcentral.com/submissions 